\title{
Unemployment Rate in Nigeria: Agenda for Government
}

\section{Eme Okechukwu Innocent}

Department of Public Administration and Local Government Studies, University of Nigeria, Nsukka, Email-okechukwunncnt@yahoo.com, okechukwunncnt@gmail.com

\section{Doi:10.5901/ajis.2014.v3n4p103}

\begin{abstract}
Nigeria has no business being rated among poor nations of the world given its human and natural resources. But in reality, this dreaded scenario is the naked truth that stares unashamedly on the faces of everyone living in the polity. Statistically speaking in the last couple of years, Nigeria's economy is one of the fastest-growing in the world while its people are the most impoverished in real terms. The events of last March 15, where millions of people scampered for about 4500 job vacancies advertised by the Nigeria Immigration Service leading to the death of about eighteen of them in an unwarranted stampede betrays the idiosyncrasy of the Nation's nominal growth without corresponding development. With global unemployment projected to reach over 215 million by 2018, experts fear that Africa, particularly Nigeria's share of the global scourge might increase disproportionately, with attendant unsavoury consequences unless the country immediately adopts pro-active and holistic approach to halt the rising youth unemployment.
\end{abstract}

Keywords: Unemployment, Economic growth and development, Job losses and job creation,

\section{Introduction}

Unemployment has become a major problem in Nigeria and millions of graduates and school leavers are busy roaming the streets in search of elusive jobs. However, government at all levels is paying lip service to creating employment opportunities for the people.

As the mass of the unemployed roams the street, government officials, elected and appointed, are busy enlarging their coast at the expense of the people. While the people are groaning under the eight poverty and penury, the government is busy reeling out statistics that the economy is growing. Some of the unemployed youths have died of frustration; while many are persevering, hoping that life will better for them.

Before penultimate Saturday, March $15^{\text {th }}$ national tragedies, the common parlance in the country has seemingly been that unemployment situation is under control with pockets of low and high profile criminal job scams recorded mostly in urban centres and reported accordingly. As reported below, official statistics have seemed to support the really a threat in the scheme of thins in Nigeria, even when it is an incontrovertible fact that compared with most advanced economies of the world like Japan and Britain, the unemployment rate in Nigeria is quite mind-boggling.

Last year, the National Population Commission said that the rate of unemployment in Nigeria rose from 21.1 per cent in 2010 to 23.9 per cent in 2011. The NPC, in a report on its website, said the nation's economic growth had not translated into job creation. It said, "Figures from the National Bureau of Statistics clearly illustrated the deep challenges in Nigeria's labour market, where the nations rapid economic growth has not translated into effective job creation. "The NBS estimates that Nigeria's population grew by 3.2 per cent in 2011, reflection rapid population growth. In 2011, Nigeria's unemployment rose to 23.9 per cent compared with 21.1 per cent in 2010(NBS,2012)."

It said the labour force swelled by 2.1 million to $67,256,090$ people, with just $51,224,115$ persons employed, leaving 16,074,205 people without work. The NPC said the lack of sufficient jobs resulted in additional 2.1 million unemployment persons in 2011, up from 1.5 million unemployed people produced in 2010. It added, "Unemployment was higher in the rural areas, at 25.6 per cent, than in the urban areas, where it was 17 per cent on average. In the light of the country's fast-growing population, efforts to create a conducive environment for job created in 2011 was reported as 209, 239 by the Federal Ministry of labour and productivity. 54\% of Nigerian youths unemployed in 2012-The National Bureau of Statistics. The National Bureau of Statistics (NBS) in late in December last year said that 54 per cent of Nigerian youths were unemployed in 2012. This fact was contained in the "2012 National Baseline Youth Survey Report" issued in Abuja by the NBS in collaboration with the Federal Ministry of Youths Development. "More than half, about 54 per cent of youth population was unemployed. Of this, females stood at 51.9 per cent compared to their male counterpart with 48.1 
per cent were unemployed," the report said. It said out of 46,836 youths recorded against different types of crimes, 42,071, representing 75.5 per cent were males, while the remaining 24.5 per cent were females. "Among the 32 different crimes committed, Marijuana (Indian hemp) smoking has the highest figure, representing 15.7 per cent. This was followed by theft and murder with 8.1 and 7.4 per cent, respectively. The respectively. The least committed crime was Immigration/Emigration representing 0.04 per cent(NBS,2012)."

According to the survey, the population of youths aged between 15 and 35 years in Nigeria is estimated to be 64 million, while females are more than males in all age groups. The report said Lagos State had the highest percentage of youths in Nigeria with 6.1 per cent, followed by Kano state representing 5.7 per cent, while Bayelsa state had the lowest with 1.3 per cent. The report said the objective of the study was to provide useful data for the design and development of youth-focused programmes by the Federal Ministry of Youths Development and other partners in the country. The study was aimed at generating empirical data to inform policy decisions and guide their implementation.

It was also aimed at providing government and other stakeholders with useful data that would assist in the development of young people's employability to ensure their successful transition to the labour market. Lagos Chamber of Commerce and Industry ( $\mathrm{LCCl}$ ) has lent its voice to the unemployment debacle in Nigeria. While reviewing the Nigerian economy at 53, last year, the chamber in a statement by its President, Goodie Ibru, lamented that unemployment rate in the country has increased by 23.9 per cent. "Unemployment rate has risen to frightening level of 23.9 per cent; youth unemployment is at 50 per cent; the poverty situation has been worsening, currently estimated at 67 per cent (just as) the security challenges have not really abated,"(Osalor,2014:18) he added.

He noted that the challenge was the inability to adequately transform the huge opportunities and potentials that abound in the country for the good of the people. He said; "the economy is inhibited by serious issues of infrastructure deficits, especially with regards to power supply, currently at less than 4000 megawatts; transportation, logistics, the quality of institutions, cost and access to funds, among others, all of which have combined to create a burden of competitiveness for domestic enterprises.

\section{Contextualizing Unemployment Rate}

Unemployment rate according to Businessdictionary (2014) refers to the percentage of total workforce who are unemployed and are looking for a paid job. Unemployment rate is one of the most closely watched statistics because a rising rate is seen as a sign of weakening economy that may call for cut in interest rate. A falling rate, similarly, indicates a growing economy which is usually accompanied by higher inflation rate and may call for increase in interest rates.

Investing Answers (2014) adds that the unemployment rate measures the percentage of employable people in a country's workforce who are over the age of 16 and who have either lost their jobs or have unsuccessfully sought jobs in the last month and are still actively seeking work. While explaining further Investing Answers (2014) using the United States America examples posits that in the U.S., the Bureau of Labor Statistics reports the unemployment rate in its Employment Situation report, which is released on the first Friday of each month at 8:30 AM EST. The report discloses the current unemployment rate, the change in the unemployment rate, and a variety of other labor statistics. The data in the report is generated by surveys taken from almost every major industry in over 250 metropolitan areas. The Bureau conducts two surveys: the household survey, which interviews 60,000 households, and the establishment survey, which reviews data from 160,000 businesses and agencies.

It is important to distinguish between the percentage of people who are unemployed and those who are simply not working. Some people may be in school full-time, working in the home, disabled, or retired. These people are not considered part of the labor force and are therefore not included in the unemployment rate. Only those people actively looking for a job or waiting to return to a job are considered unemployed. Economists generally distinguish between three different types of unemployment. Frictional unemployment exists when a lack of information prevents workers and employers from becoming aware of each other. It is usually a side effect of the job-search process, and may increase when unemployment benefits are attractive. Structural unemployment occurs when changing markets or new technologies make the skills of certain workers obsolete. And finally, cyclical unemployment is a result of the cyclical nature of the economy and occurs whenever there is a general downturn in business activity.

Unemployed people typically fall into one of four classifications. Job losers are people who have been laid off or fired, either temporarily or permanently. On the other hand, job leavers are people who have voluntarily left their jobs, and the size of this group may actually reflect confidence in the state of the economy. New entrants are people seeking employment for the first time. And finally, re-entrants are people who left the labor force for a time and are now returning, such as parents who opted to raise families or those who left to pursue additional education. Some level of 
unemployment will always be present in an economy as industries expand and contract, as technological advances occur, as new generations enter the labor force, and as workers voluntarily search for better opportunities. This is why most economists agree that there is a natural rate of unemployment in the economy (usually $4 \%-6 \%$ ). This natural rate is most affected by the number of youthful workers in the labor force, as well as public policies that discourage employment or job creation, such as a high minimum wage, generous unemployment benefits, and few disincentives associated with laying off workers.

Justifying why unemployment rate is significant for her economy, Investing Answers (2014) asserts that employment is the primary source of personal income in the U.S. and has a major influence on consumer spending and overall economic growth. Thus, the unemployment rate, which is a lagging indicator, can provide considerable information about the state of the economy or the health of particular business sectors. For example, high unemployment generally indicates that an economy is underperforming or has a falling gross domestic product. Conversely, low or falling unemployment may reflect an expanding economy. At the same time, unemployment data can also point to changes in certain industries. For example, an increase in construction jobs might signal improving housing starts. For these reasons, the unemployment rate is one of the most widely followed economic indicators

While there is some controversy over the different methodologies used to measure unemployment, nearly all recognize its importance. Because unemployment statistics are so closely watched and heavily relied upon, differences between the expected unemployment rate and the reported rate may have a wide impact, not only in the securities markets, but also in the value of the U.S. dollar (which tends to rise in a strengthening labor market). Furthermore, unexpectedly low unemployment may motivate the Federal Reserve to increase interest rates in order to curb a possibly overheating economy, and vice-versa. This will also influence stock and bond prices.

Bureau of Labor Statistics (2014) warns that the official definition of the unemployment rate, given above in a series of definitions, contains a couple of unavoidable complications. (1) A person who loses a 40 hour per week job, but works for one hour mowing a lawn for pay is classified as employed. (2) A person who simply expresses interest in having a job is classified as unemployed. "Discouraged workers" who have lost a job, but do not make an effort to find a new job in a given week are not classified as unemployed or even as in the labor force. Both possibilities mean that the announced unemployment rate is not as definitive as it might sound.

Nonetheless, the unemployment rate is defined as the number of unemployed persons divided by the labor force, where the labor force is the number of unemployed persons plus the number of employed persons. The official definitions of these figures as documented by Bureau of Labor Statistics (2014) are as follows: Persons 16 years and over in the civilian non-institutional population who, during the reference week, (a) did any work at all (at least 1 hour) as paid employees, worked in their own business, profession, or on their own farm, or worked 15 hours or more as unpaid workers in an enterprise operated by a member of the family, and (b) all those who were not working but who had jobs or businesses from which they were temporarily absent because of vacation, illness, bad weather, childcare problems, maternity or paternity leave, labor-management dispute, job training, or other family or personal reasons, whether or not they were paid for the time off or were seeking other jobs. Each employed person is counted only once, even if he or she holds more than one job. Excluded are persons whose only activity consisted of work around their own house (painting, repairing, or own home housework) or volunteer work for religious, charitable, and other organizations.

Persons 16 years and over who had no employment during the reference week, were available for work, except for temporary illness, and had made specific efforts to find employment sometime during the 4-week period ending with the reference week. Persons who were waiting to be recalled to a job from which they had been laid off need not have been looking for work to be classified as unemployed.

For our purpose the unemployment rate can be defined as the number of people actively looking for job divided by the labour force. Changes in unemployment depend mostly on inflows made up of non-employed people starting to look for jobs, of employed people who lose their jobs and look for new ones and of people who stop looking for employment.

Domesticating the characteristics in Nigeria, Obinna (2014) explains that the rate of unemployment in the country is expected to increase further by about two per cent this year, The Financial Derivatives Company Limited (FDC), report has predicted. The Financial Derivatives Company Limited (FDC), a Lagos-based financial advisory firm stated this in its 2014 outlook obtained recently. According to the National Bureau of Statistics (NBS), the rate of unemployment in Nigeria stood at 23.9 per cent in 2011, while urban unemployment was estimated at 29.5 per cent in 2013.

In addition, the FDC report also forecast that the misery index would likely to increase further in 2014, from the 38 per cent it stood in 2013. It also predicted that the nation's currency would fall by about three per cent this year, even as it anticipated a correction in the stock market. The report equally stated that inflationary pressure would manifest this year, adding that the Consumer Price Index (CPI) which stood at 7.9 per cent as at November 2013, may increase to between 
9.5 and 11 per cent. "External reserves to deplete further to $\$ 40$ billion. Recurrent expenditure projected to increase to 72.71 per cent of total government spending," . Furthermore, the report predicted that the net Foreign Direct Investment (FDI) would decline to $\$ 4.8$ billion in 2014 , adding that the United States tapering of its quantitative easing programme would trigger capital flow reversal.

The report showed that in 2013, power generation declined as the naira shed 12 per cent at the parallel market, while the exchange rate divergence ratio widened. In the review period, external reserves declined to $\$ 43$ billion, with net FDI declining to $\$ 5.3$ billion as trade balance decreased to $\$ 40.2$ billion. Nigeria is ranked 37 th largest economy in the world (with GDP of $\$ 283$ million) and is projected to rise to 13th position in 2020. The countries potential GDP growth declined to 11 per cent, the report added.

Equally in a separate report released recently yesterday, an Economist at Renaissance Capital, Charlie Robertson pointed out that with the proposed rebasing of the country's GDP next month, the Nigerian economy would become the biggest in Africa at over $\$ 400$ billion.

"Electricity reform is working. Growth of seven per cent a year since 2000 means Nigeria's GDP is on course to be bigger than 2012 Japan by 2050, at over $\$ 5$ trillion in today's money by 2050. We like Nigeria for the first quarter of 2014," (Obinna, 2014) Robertson added.

\section{Growing Rate of Unemployment in Nigeria: Causes and Intervention Programmes}

Statistics from the National Bureau of Statistics (NBS) show that Nigeria's unemployment rate rose from 21.1 per cent in 2010 to 23.9 per cent in 2011. The labour force swelled by 2.1 million to $67,256,090$ people, with just $51,224,115$ persons employed, leaving 16,074,205 people without jobs. Insufficient jobs resulted in additional 2.1 million unemployed persons in 2011, up from 1.5 million in 2010, even as Nigeria's population, according to NBS, grew by 3.2 per cent in 2011, from 159.3 million people in 2010 to 164.4 million in 2011.

NBS however, added that, "Unemployment was higher in the rural areas, at 25.6 percent, than in the urban areas, where it was 17 per cent on average." NBS however, admonished that in the light of the country's fast growing population, there is need to double efforts at creating a conducive environment for job creation in order to reverse the trend. Therein lies Nigerian's fears. For instance Akintude Maberu told The Nation that "government is yet to come up with conscientious and people-oriented policies targeted at getting millions of unemployed Nigerian youths actively and meaningfully engaged"(Okorocha, 2014:5).

While noting that unemployment remains one of the major concerns in the country today, the renowned fiancé analyst and stockbroker dismissed current federal government's programmes aimed at creating jobs as "more propaganda." He argued that reversing the trend of rising youth unemployment must start from the nation's education sector, which he said must be overhauled along the line of skills acquisition. Hear this: "Nigeria's education curriculum should be immediately revised to incorporate entrepreneurial skills and enterprise development. This would adequately horn the entrepreneurial skills of Nigerian youths (Okorocha, 2014:5).

The idea, Maberu explained, is that with adequate skills and hands-on experience in various vocations, Nigerian graduates would be self employed after leaving school while those in school would find something doing even before completing their education. He said that this would save Nigerian youths the stress and trauma of endless and fruitless search for paid employments in a highly saturated labour market. The approach, according to him, has become even more necessary considering the fact that many Nigerian graduates are unemployable.

Maberu also took a swipe at the structure of Nigeria's civil service which, according to him, is not structured in a way that allows qualified youths take up vacant positions left by retired civil servants in an open and transparent manner. While conceding that indeed, few employment opportunities exist in the country, he however, expressed regrets that the few job openings in various government ministries, departments and agencies (MDAs), unlike in the past, are no longer openly advertised. He asked,

When was the last time you saw job advertisements in the papers by any of the MDAs? adding, you hardly see advertisements for jobs these days, and until there is a progressive shift from bottom up, allowing civil servants in MDAs to genuinely retire and make room for the younger ones instead of reserving those jobs for their cronies, the rising unemployment trend in the country may never be reversed (Okorocha, 2014:5).

Maberu argued that the need for more concerted and holistic efforts to reverse the rising youth unemployment has become even more necessary considering the grim picture painted recently of the global unemployment market by the International Labour Organization (ILO). ILO (2014) projected that global unemployment would hit over 215 million by 2018. The organization in its 'Global Employment Trends 2014' noted that the uneven economic recovery and successive 
downward revisions in economic growth projections have had an impact on the global employment situation with the result that about 202 million people were unemployed in 2013 around the world.

The figure, according to ILO (2014), is an increase of almost 5 million compared with the year before, reflecting the fact that employment is not expanding sufficiently fast to keep up with the growing labour fore. ILO(2014) said the bulk of the increase in global unemployment is in the East Asia and South Asia regions, which together represent more than 45 per cent of additional jobseekers, followed by Sub-Saharan Africa and Europe. Latin America, by contrast, added fewer than 50,000 additional unemployed to the global number-or around 1 per cent of the total increase in unemployment in 2013.

ILO (2014) said overall, the crisis-related global jobs gap that has opened up since the beginning of the financial crisis in 2008, over and above an already large number of jobseekers, continues to widen. ILO (2014) projected that in 2013, this gap reached 62 million jobs, including 32 million additional jobseekers, 23 million people that became discouraged and no longer look for jobs and 7 million economically inactive people that prefer not to participate in the labour market and on current trends, it would rise by a further 13 million people by 2018. It also said that if current trends continue, "global unemployment is set to worsen further, albeit gradually, reaching more than 215 million jobseekers by 2018. During this period, around 40 million net new jobs would be created every year, which is less than the 42.6 million people that are expected to enter the labour market every year.

ILO (2014) however, said that young people continue to be particularly affected by the weak and uneven recovery. "It is estimated that some 74.5 million young people-aged 15-24-were unemployed in 2013; that is almost 1 million more than in the year before. He global youth unemployment rate has reached 13.1 per cent, which is almost three times as high as the adult unemployment rate. In all, ILO (2014) says that tackling the employment and social gaps requires jobfriendly macroeconomic policies. The report said. In all, ILO (2014) says that tackling the employment and social gaps requires job-friendly macroeconomic policies. The report said that a rebalancing of macroeconomic policies and increased labour incomes would significantly improve the employment outlook.

Although, the ILO (2014) report did not place Sub-Saharan Africa, by extension, Nigeria, among those that would account for the bulk of the increase in global unemployment, the situation in Africa is quite worrisome, particularly with regards to youth unemployment. According to the ILO (2014), 3 out of 5 unemployed people in Africa are young people. There are 200 million people in Africa between 15 and 24 years of age, representing about 20 per cent of the population. The continent is said to have the fastest growing and most youthful population in the world. Over 40 per cent of its population is under 15 . Africa's high fertility rate is said to be responsible for this.

Indeed, in Africa, youth unemployment has become a threat to socio-economic peace and stability. For instance, unemployment rate in South Africa increased to 25.20 per cent in the first quarter of 2013 from 24.90 per cent in the fourth quarter of 2012. Kenya's reached an all time high of 40.0 per cent in December 2011, while Ghana, Nigeria's close neighbour, had an unemployment rate of 11 per cent in 2012. Nigeria, Africa's most populous country, has 23.9 per cent unemployment rate, with youth unemployment rate estimated at over 50 percent.

Experts however, say that the unemployment figure for Nigeria might be higher considering the unavailability of reliable data in the country. Some experts argue that given Nigeria's penchant for poor record keeping, the figure could be as high as 37.7 per cent. Besides, over one million graduates are churned out annually by well over 300 universities, polytechnics and colleges of education in Nigeria, with many people expressing fears that the country's economy is at moment not robust enough to absorb even 20 per cent of the products of the institutions(Eme,2013).

As if to make matters worse, more companies, in a bid to cut cost, are downsizing their workforce thus sending thousands of their employees bank to the labour market. The banking sector appears to be worse hit following a sack gale that has shown many bank workers the door while keeping others on edge. The telecoms sector is also hit as telecoms companies are laying off their workers after out-sourcing most of their operations. Many of the workers who have been sacked are bread winners and their lives and that of their families and dependants are now hanging on the balance.

The increasing rate of unemployment in the county is seen by experts as confirmation that Nigeria's widely reported rapid economic growth has evidently failed to translate into job creation. For instance, Prof. Pat Utomi, Director, Lagos Business School, has never stopped wondering why Nigeria experiences rising rate of unemployment despite its rating as one of the fastest growing economies in the world, a situation said to be no different in six other African countries listed among the 10 fastest growing economies in the world(Agboola,2014).

The NBS equally pointed out that 54 per cent of Nigerian youths were unemployed in 2012, of this figure, females stood at 51.9 per cent and male 48.1 per cent. In a related development, the former chairman of the subsidy reinvestment employment programme (SURE-P), Dr. Christopher Kolade bemoaned the rising rate of unemployment in the country, 
saying that no fewer than 40 million Nigerians are without jobs. The minister of Finance and co-ordinating minister of the economy, Dr. Ngozi Okonjo-Iweala also admitted that the spate of unemployment was really alarming. Quoting the NBS, she declared that 1.8 million young Nigerians enter into the labour market. It is very instructive to note that, Nigeria was ranked 153 out of 186 countries in the 2013 United Nation's Human Development Index(Akadoro,2014).

The World Bank states that job creation in Nigeria has been inadequate to keep pace with the expanding working age population, causing social distress for an increasing number of Nigerian youths. Similarly, the statistician General of the Federation and the Chief Executive Officer of NBS, Dr. Yemi Kale said, unemployment was highest amongst youths aged 15-24 and 25-44 adding that the problem was more pronounced in the rural area. So bad is the situation that if urgent and workable decisions are not taken, it could be capable of far-reaching cataclysmic consequences(Salif,et.al, 2014).

More and more people do not have purchasing power; and les consumption has led to lower production hindering economic growth. Ineffective government development programmes as well as lack of institutional capacity to provide jobs due to under-funding have not helped matters. A fallout of unemployment is the recourse to kidnapping, armed robbery, prostitution, militancy, insurgency, street begging, hawking, cyber crimes and proliferation of baby manufacturing dens just to mention some of the escalating social vices.

Unemployment situation in Nigeria has become a conundrum. Not long ago, the Dangote Industries Limited, DIL, announced its intention to recruit just 100 derivers with Ordinary National Diploma certificate to drive its newly acquired state-of-the-art trucks. In the scheme tagged Executive Truck Drivers, about 13,000 young Nigerians turned up for the interview. But that was not even surprising considering the level of unemployment in the country. What shocked many Nigerians was the fact that of the 13,000 applications, six were Ph.D holders, 704 master's degree holders and over 8,460 bachelor degree holders(Obike,2014).

A bemused Aliko Dangote, President of DIL, said that most of the applicants were from reputable universities and had the needed qualification. The attraction of the offer was that the drivers would eventually take possession of the tucks. In addition to getting allowances on each trip along with their salaries, they were to own the trucks at no interests after they must have reached 300,000 kilometres, which is about 140 trips from Lagos to Kano. Dangote said a hard working driver could complete such distance in two years, while it may take lazy ones up to four years(Nnaqdozie,2014).

The unemployment situation in the country is worsened by mass retrenchment tin various sectors of the economy where companies have had to restructure their operations or even shut down their factories due to the harsh operating environment. A clear example is the banking sector where thousands of workers have been thrown into the employment market on a yearly basis. Sunday Salako, national president, Association of Senior Staff of Banks, Insurance, and Financial Institutions, ASSBIFI, confirmed that about 10,000 of the association's members have lost their jobs since 2009(Nwaeze,2014).

Ironically, while the unemployment situation is worsening, the nation's economy is rated as one of the fastest growing economies in the world. The National Bureau of Statistics, NBS, puts the growth rate of the economy for 2013 at 6.75 per cent, which Ngozi Okonjo-Iweala, minister of finance and coordinating minister for the economy, says is conservative given that the International Monetary Fund, IMF, rates it at 7.2 per cent. Nigeria has the highest growth rate in Africa and one of the highest in the world. China's economy is growing at 7.75 per cent with a downward forecast of 0.25 per cent for 2014; South Africa is growing at 3.3 per cent; while IMF cut down the world economic growth which was 3.3 per cent in April 2013 to 3.1 per cent in July 2013. This suggests that the Nigerian economy is growing at more than two times the global average(Osalor,2014).

Prof. Akpan Ekpo, Director-General, West African Institute for Financial and Economic Management (WAIFEM), is no less worried, noting that in Nigeria, despite the 'healthy growth' of the economy in the last five years (averaging almost 7 per cent), unemployment has been rising alongside the increased incidence of poverty. He described the country's rising unemployment as "a looming time bomb and a national crisis(Salif,et.al,2014)."

Ekpo is right. The rising violent crimes and the widespread insecurity across the country, many people believe, is largely traceable to the rising unemployment in the last couple of years. To day, kidnapping, advance fee fraud, otherwise called 419, armed robbery, prostitution, cultism, drug and child trafficking, among others, have become daily occurrences. A new and scary dimension has since been added to these social ills following the upsurge in violent campaigns by terrorist groups, particularly the dreaded Boko Haram insurgents. Many Nigerian youths, for lack of paid employments, have become ready recurs into terrorist organizations, a development that confirms fears that the country is indeed, seating on a keg of gunpowder.

But government says it is not folding its arms and that it is making progress in reversing the rising trend of unemployment. For instance, the Coordinating Minister for the Economy and Minister of Finance, Dr. Ngozi Okonjo- 
Iweala, disclosed recently that the YouWin programme, an acronym for Youth Enterprise with innovation in Nigeria, which seeks to support thousands of youth entrepreneurs to grow their businesses and create jobs for other youths, has so far created close to 20,000 jobs. About 2, 400 winners are said to have emerged from the first two rounds of the unique business plan competition, coordinated by the Federal Ministry of Finance, along with the ministries of communications technology and youth development. Government is also making progress in job creation through the Subsidy Reinvestment and Empowerment Programme (SURE-P) through which it hopes to create about 370,000 jobs-which experts say are, at best, mere drops in the ocean. They therefore, argue that a more pro-active, comprehensive and honest approach must be fashioned out to stop the rising unemployment scourge. The thinking is that with an ever increasing youth population who have no jobs, it is only a matter of time before Nigeria erupts into a serious crisis. Whether government would act decisively to starve off the impending crisis remains to be seen.

In the scholarly opinion of Dr. Oluseyi A. Shadare of Department of Industrial Relations and Personnel Management, University of Lagos, "Planning for human resources use in Nigeria has been based on guesswork. Rational steps taken by most management to cope with the recession include ban on recruitment. The practice of natural wastage, which involves the refusal to fill vacancies imply that job seekers are directly hit. Though the rate of appointment of expatriates has been slowed since 1982, presently a reasonable percentage of the labour force in Nigeria is still dominated by foreigners. Most private and even public institutions tend to see the NYSC as a means of securing cheap labour. They utilize the Services Corp members each year but tend not to absolve any substantial number at the end of the service year. The adoption of the policy of last-in-first out by labour and management, coupled with ban on recruitment seemed to exert a great impact on the employment situation of university graduates. Existence of artificial barriers to geographical mobility of labour, cultural employment practices, localization and truncating of potentials along tribal lines.

He continued, "Since the middle of the 1970s, the policy of increased enrolment and turnout of university graduates was aimed at easing some of the development problems identified above. It was hoped that by providing the required quality and quantity of different manpower the nation can advanced at a faster pace. Hence the incidence of graduate unemployment is indeed an unfortunate problem, as these graduates find it difficult to enter labour activities to generate growth and development for the economy". And, Professor C.G.E. Salami of Department of Business Administration and Marketing, Faculty of Management Sciences, Delta State University, Asaba, avers that "most intervention programmes have been poorly coordinated and in some cases either overlap or contradict one another. Beginning with the Directorate of Food Road and Rural Infrastructure (DFRRI), National Directorate of Employment (NDE), Family Support Programme (FSP) and now the National Economic Empowerment Development Strategies (NEEDS), SEEDS and even the establishment of People Bank of Nigeria (PBN) are some of the intervention programmes were intended to promote employment generation. Most of the past intervention programmers were implemented as ad-hoc, poorly coordinated and marred by corruption and inefficiency. Consequently, rather than reduce unemployment, the reverse seems to be the case. The Nigerian Living Standard Survey (NLSS, 2006) estimated the poverty level at 54\%, implying that approximately 75 million Nigerians were unemployed. The tables below captures the magnitude in Nigeria.

Table 1: Nis Recruitment Data 2014

\begin{tabular}{|c|c|c|}
\hline $\mathbf{S} / \mathbf{N}$ & State & Figure \\
\hline 1 & Abia & 23,500 \\
\hline 2 & Adamawa & 25,504 \\
\hline 3 & Akwa Ibom & 18,750 \\
\hline 4 & Anambra & 15,990 \\
\hline 5 & Bauchi & 27,850 \\
\hline 6 & Bayelsa & 16,888 \\
\hline 7 & Benue & 10,623 \\
\hline 8 & Borno & 9,852 \\
\hline 9 & Cross river & 5,810 \\
\hline 10 & Delta & 6,221 \\
\hline 11 & Ebonyi & 14,852 \\
\hline 12 & Edo & 19,531 \\
\hline 13 & Ekiti & 22,851 \\
\hline 14 & Enugu & 35,811 \\
\hline 15 & FCT & 102,512 \\
\hline 16 & Gombe & 32,653 \\
\hline
\end{tabular}


Candidates $=1,254,959$

\begin{tabular}{|c|c|c|}
\hline 17 & Imo & 31,623 \\
\hline 18 & Jigawa & 25,621 \\
\hline 19 & Kaduna & 26,661 \\
\hline 20 & Kano & 18,812 \\
\hline 21 & Katsina & 15,900 \\
\hline 22 & Kebbi & 17,821 \\
\hline 23 & Kogi & 13.213 \\
\hline 24 & Kwara & 21,213 \\
\hline 25 & Lagos & 81,852 \\
\hline 26 & Nasarawa & 21,521 \\
\hline 27 & Niger & 12,531 \\
\hline 28 & Ogun & 32.590 \\
\hline 29 & Ondo & 29,852 \\
\hline 30 & Osun & 31,111 \\
\hline 31 & Oyo & 53,895 \\
\hline 32 & Plateau & 23,123 \\
\hline 33 & Rivers & 18,531 \\
\hline 34 & Sokoto & 42,123 \\
\hline 35 & Taraba & 32,121 \\
\hline 36 & Yobe & 41,213 \\
\hline 37 & Zamfara & 21,334 \\
\hline & Total & $1,254,959$ \\
\hline
\end{tabular}

Recruitment fee $=\mathrm{N} 1,000$

Total revenue to NIS $=\mathrm{N} 1,254,959,000$.

(one billion, two hundred and fifty-four million, nine hundred and fifty-nine thousand naira)

Source: General Household Survey Report/NBS/CBN Surveys.

Table 2: Unemployment trend in Nigeria, 2010-2014

\begin{tabular}{|l|l|l|}
\hline 2010 & 21.1 & Per cent \\
\hline 2011 & 23.9 & Per cent \\
\hline 2012 & 24.3 & Per cent \\
\hline 2013 & 28.5 & Per cent \\
\hline 2014 & $30 \%$ & Projection \\
\hline
\end{tabular}

Table 3: Unemployment Rates by State 2007-2011

\begin{tabular}{|c|c|c|c|c|c|c|}
\hline S/N & State & $\mathbf{2 0 0 7}$ & $\mathbf{2 0 0 8}$ & $\mathbf{2 0 0 9}$ & $\mathbf{2 0 1 0}$ & $\mathbf{2 0 1 1}$ \\
\hline 1 & Abia & 25.1 & 11.9 & 14.5 & 22.8 & 11.2 \\
\hline 2 & Adamawa & 21.5 & 13.5 & 29.4 & 24.6 & 33.8 \\
\hline 3 & Akwa Ibom & 18.0 & 11.1 & 34.1 & 27.7 & 18.4 \\
\hline 4 & Anambra & 14.9 & 7.3 & 16.8 & 10.8 & 12.2 \\
\hline 5 & Bauchi & 20.5 & 6.9 & 37.2 & 27 & 41.4 \\
\hline 6 & Bayelsa & 21.9 & 67.4 & 41.5 & 27.4 & 23.9 \\
\hline 7 & Benue & 7.9 & 7.8 & 8.5 & 6 & 14.2 \\
\hline 8 & Borno & 12.5 & 11.8 & 27.7 & 26.7 & 29.1 \\
\hline 9 & Cross river & 32.8 & 18.9 & 14.3 & 27.9 & 18.2 \\
\hline 10 & Delta & 22.9 & 11.5 & 18.4 & 27.9 & 27.2 \\
\hline 11 & Ebonyi & 7.9 & 5.1 & 12 & 25.1 & 23.1 \\
\hline 12 & Edo & 14.8 & 15.6 & 12.2 & 27.9 & 35.2 \\
\hline 13 & Ekiti & 11.4 & 11.5 & 20.6 & 28 & 12.1 \\
\hline 14 & Enugu & 14.1 & 10.5 & 14.9 & 28 & 25.2 \\
\hline 15 & Gombe & 16.9 & 7.6 & 32.1 & 27.2 & 38.7 \\
\hline 16 & Imo & 28.3 & 17.4 & 20.8 & 28.1 & 26.1 \\
\hline 17 & Jigawa & 27.0 & 5.9 & 26.5 & 14.3 & 35.9 \\
\hline 18 & Kaduna & 8.7 & 12.7 & 11.6 & 12.4 & 30.3 \\
\hline 19 & Kano & 10.1 & 5.8 & 27.6 & 14.7 & 21.3 \\
\hline
\end{tabular}




\begin{tabular}{|c|c|c|c|c|c|c|}
\hline 20 & Katsina & 10.9 & 11.8 & 37.3 & 11 & 28.1 \\
\hline 21 & Kebbi & 1.3 & 16.5 & 12 & 10.7 & 25.3 \\
\hline 22 & Kogi & 14.6 & 16.4 & 19 & 9.5 & 14.4 \\
\hline 23 & Kwara & 17.7 & 10.2 & 11 & 2.7 & 7.1 \\
\hline 24 & Lagos & 13.7 & 7.6 & 19.5 & 27.6 & 8.3 \\
\hline 25 & Nasarawa & 11.8 & 17 & 10.1 & 3.4 & 36.5 \\
\hline 26 & Niger & 4.2 & 3.9 & 28 & 11.7 & 39.4 \\
\hline 27 & Ogun & 3.6 & 5.8 & 8.5 & 27.8 & 22.9 \\
\hline 28 & Ondo & 6.7 & 6.3 & 14.9 & 28 & 12.5 \\
\hline 29 & Osun & 7.2 & 6.5 & 12.6 & 27.6 & 3 \\
\hline 30 & Oyo & 8.1 & 8.7 & 14.9 & 27.7 & 8.9 \\
\hline 31 & Plateau & 6.8 & 4.7 & 7.1 & 10.4 & 25.3 \\
\hline 32 & Rivers & 66.4 & 12.1 & 27.9 & 27.8 & 25.5 \\
\hline 33 & Sokoto & 12.3 & 5.9 & 22.4 & 15.9 & 17.9 \\
\hline 34 & Taraba & 15.2 & 19.9 & 26.8 & 24.7 & 12.7 \\
\hline 35 & Yobe & 24.4 & 12.8 & 27.3 & 26.2 & 35.6 \\
\hline 36 & Zamfara & 19.1 & 16.4 & 13.3 & 14.5 & 42.6 \\
\hline 37 & FCT & 47.8 & 8.7 & 21.5 & 11.8 & 21.1 \\
\hline 38 & Nigeria & 12.7 & 14.9 & 19.7 & 21.4 & 23.9 \\
\hline
\end{tabular}

Source: General Household Survey Report/NBS/CBN Surveys.

Yemi Kale, statistician general of NBS, gave an insight into the ever-rising unemployment rate. Said he:

The problem with jobs is that if you are generating jobs and more people are entering the job market than you can generate, you might have a problem. It is wrong to say that things are not improving. Things are improving, jobs have been created, but the challenge is how can we increase the number of these jobs to balance out? (Salif, et al, 2014:15)

Indeed, every year not less than 80,000 graduates of universities and polytechnics are thrown into the employment market. Maharazu Tsiga, brigadier-general and director-general, National Youth Service Corps, NYSC, recently raised an alarm that the number of graduating students from universities and polytechnics would soon rise to half a million per year.

It does not require rocket sickness to know why the unemployment situation is worsening. The fact that more graduates are being churned out by the schools is said to be a function of the ever-rising population and increasing access to institutions of higher learning. for instance, the NBS estimates that Nigeria's population grew by 3.2 per cent in 2011, from 159.3 million people in 2010 to 164.4 million in 2011. now, that is not taking into consideration the scores of young Nigerians who are yearly denied admission into these schools or have to go offshore for tertiary education(Eme,2013).

The federal government insists that job creation tops its Transformation Agenda. It targets that the agriculture sector would produce about 3.5 million jobs by 2015. Okonjo-Iweala said the YouWin programme would create 14,000 jobs are expected to be created from the second trenched while the third would create about 110,000 jobs. The graduate internship programme is expected to absorb 50,000 graduates as first batch. Of this number, 1,309 graduates have been so fare placed while 1,000 private firms have already applied to participate in the programme. The community services programme is expected to absorb 730,000 job seekers. Out of these, government says that 178,000 jobs have been created. But the quality of these jobs has been criticized as low level (Salif, et al, 2014:15).

The minister explained that this is a programme designed to support entrepreneurship. It is a business planning competition for youths, 40 and below who have great business ideas to put them into a business plan. they compete openly and on merit. They are finally given a grant of between one million and N10 million to boost their businesses and help them to double or triple employment within those businesses. This is done strictly on merit. Everything is done online.

As a way of creating more jobs in the system, the government according to the minister initiated some policy measures, key of which is the agricultural transformation agenda designed to boost employment generation by creating agricultural value chains. The agric scheme did not have the desired impact because farmers still complain of lack of support from government. although the federal government approved N15 billion revolving loan to farmers at single-digit interest rate to stimulate the agriculture sector, a short-term intervention fund to be disbursed by the Bank of Agriculture, most farmers said they could not access the fund because of the cumbersome requirements. Those who accessed the loan complained that flooding affected their farmlands, washing away most of their produce.

Apart from the efforts at the federal level, quit a number of state governments are also known to be empowering 
their citizens through creation of jobs. For in stance, Human Capital Development is one of the pillars of Governor Emmanuel Uduaghan's Transformation Agenda in Delta State. Through its micro-credit scheme, the government has economically empowered no fewer than 85,367. Under the Rapid//ncreasing Food Programme over 1,000 farmers were assisted in the state to cultivate 186 hectares of rice farmland; 33 hectares of cowpea; 20.5 hectares of tomatoes; 300 hectares of maize; and 60 hectares of plantain. The state government is equally exploring opportunities in the tourism industry, through a multi-million Leisure Resort project, that will provide employment for over 6,000 youths in the state and further enhance economic activities in the two host communities-Oleri village in Udu Local Government, LG, area where the main park is located and Ogwashi-Ukwu in Aniocha LC where the animal reserve and wild park are located (Osalor,2014).

Chibuike Amaechi, governor of Rivers State, is also in the forefront of job creation. Under his administration, the embargo on employment was lifted with the initial employment of 46 civil servants across cadres in 2008. then in 2009, the state government employed 605 workers into the civil service. And by 2010, no fewer than 77 others were employed. While the government has continued to engage more workers into the civil service, it has also not relented in promoting them as and when due (Nwaeze,2014).

A Sports City built by the administration has employed over 1,000 persons, just as Songhai Farms established by Amaechi has engaged over 2,000 workers. 10,000 teachers were employed in a fell swoop by the government last year, following demands by labour leaders for job creation in the state. the resuscitation of Risonpalm is expected to create about 4,000 jobs when the estate fully comes into operation. He multi-purpose shopping mall located at the front gate axis of e government house is ongoing. Upon completion, it is expected to create jobs for about 600 workers. The story is the same across the country, how state and local governments are creating jobs, thereby empowering Nigerians. But the jobs are far in-between, considering the ballooning population of the country and its growing labour force(Nnadozie,2014).

Another key issue is also the employability of Nigerian graduates. Many chief executives of big and small companies complained during the National Economic Summit, NES, in Abuja recently, about lack of relevant skills among job seekers-a situation that has forced most of them to recruit skilled personnel from other countries, even in nearby African countries like Ghana, Cameroon and the Republic of Benin.

Tony Elumelu, former Group Managing Director, United Bank for Africa, declared pointedly that most of the graduates were unemployable because of the deficiency in the country's educational system. He said vocational skills were grossly lacking in the country and that many companies go to neighbouring countries like Ghana to recruit personnel with technical competence. He advocated for a review of school curricula in the country, stressing that vocational skills should be thought in schools and more technical colleges should be established (Agboola,2014).

The four-year Transformation Agenda of the President Jonathan administration ends this year without any prospect that the situation would be better. The power sector reform, on which the government also hinged its hope of job creation, is yet to be completed. Although the Power Holding Company of Nigeria has been unbundled and privatized, the investors are still struggling with teething problems that have delayed hope of improvement in electricity and by implication more jobs from the private sector.

There appears to be a great deficit in government's employment generation policies that urgently need to be bridged. This is, perhaps, why the Senate said it would soon form a committee to brainstorm on a holistic roadmap for employment in the country.

Okonjo-Iweala sees entrepreneurship education as the solution to tackling unemployment in the country. Lere Baale, director, Business School Netherlands, Nigeria, noted that there is need for individuals, even within paid employment, to think of entrepreneurship. According to him, while many individuals have risen to the peak of their careers successfully, growing multi-national businesses, many of them have failed to achieve the same feat as entrepreneurs. He argues that these individuals are unable to do so because their professional training and the Nigerian educational system did not equip them with such abilities. He stated that "Our educational system must be structured in such a way that every professional is taught entrepreneurship courses throughout the duration of their educational programmes" ().

As a way out of the unemployment quagmire, experts canvass for the involvement of the private sector to save the day. For example, the telecoms and the manufacturing sectors have created thousands of jobs following the liberalization of the telecoms sector and the introduction of the import substitution policy that has transformed the cement sector. Dangote group alone has created about 60,000 direct and indirect employments, mainly through his cement factories across the country. The Dangote refinery soon to be established will also employ 8,000 engineers and create jobs for 85,000 Nigerians (Odidi,2014).

In the telecoms sector, it is estimated that at least 10,000 direct jobs and between one million to three million 
indirect jobs in the forms of recharge card vendors and merchants of phone accessories were created since the sector was liberalized. Segun Ogunsanya, chief executive officer, CEO, Airtel Nigeria, said nearly 1,000 direct and full-time positions are created each year (Odidi,2014).

Experts insist that government can replicate the revolution in cement manufacturing and telecoms in other sectors by evolving appropriate policies to encourage private sector investment to drastically reduce unemployment in the country. Ituah Ighodal, an accountant, argues that while it is governments, responsibility to establish an enabling environment for job creation, Nigerian must realize that in tackling the current spate of unemployment in the country, individuals need to embrace entrepreneurship. Ighodalo expressed worry that the country is faced with the current spate of unemployment because of the inability of Nigerians to think creatively. He urged Nigerians to begin to identify opportunities available and proffer solutions as entrepreneurs. For instance, he identified the challenges of the country's waste disposal system as an opportunity to create waste recycling businesses (Akadoro,2014).

Lolu Akinwunmi, chief executive officer, Prima Garnet Africa, noted that Nigerian shave always had in them, the spirit of entrepreneurship. He believes the nation's economy has thrived for this long because of the small-scale businesses that are available in the nation. Laura Oloyede, chief operating officer, Cutler Communications, shares Akinwunmi's view saying; "We believe that tackling the unemployment situation in Nigeria is not about pushing for government to create more jobs; rather we should look for innovative ways to tackle unemployment collectively"(Obike,2014).

\section{Recommendations}

To this end, government must ensure necessary modifications in the educational system in the country that would make graduates to be employers of labour and self-employed, instead of looking for scarce job opportunities. The acquisition of the right skills to fit the various needs of the society is imperative. However, the oft-repeated cliché that Nigerian graduates are unemployable is as a result of apparent failure of government to pro-actively address the deficiencies in the educational system.

To effectively deal with the unemployment situation in the country, the government must also exigently attend to the nagging issue of infrastructural deficits in the country, especially the issue of power supply. The national economy need a strategic diversification from oil and gas to solid minerals, aviation, tourism, agriculture. Small and Medium Scale Enterprises as well as the manufacturing sector should become the real engine of growth and employment generation, backed by the enabling environment for private investments. We also advocate for a comprehensive national policy on employment to drastically reduce unemployment ratio in the country to the barest minimum.

Again, the national economy should be managed in such a manner that would have direct bearing on the wellbeing of the generality of the people. After all, the economy cannot exist in a vacuum; also government should address the gross underutilization of resources to deal with pervasive unemployment in the country. Government must be courageous enough to put in place homespun economic policies devoid of any misanthropic tendencies and reject foreign induced anti-people economic agenda. Government must get to the brass task of tackling the serious problem of corruption with all the attention it deserves. Also, social security schemes must be created to curb the fangs of unemployment amongst the teeming population.

Furthermore, with the new industrial policy of the federal government anchored on the support for the establishing of at least one cottage industry in each of the 774 local governments in Nigeria, an industrial fund should be made handy for local entrepreneurs to access. Again series of business clinics aimed at promoting entrepreneurship intended to serve as a "one-stop solution centre for business problems and capacity building for trade groups in the industrial sector "should be organized by government at every level to generate employment.

Added to this is the fact that with the massive unemployment situation in the country, many governments are not paying even the minimum wage pegged at $\mathrm{N} 18,000$ which could provide some succor. It is scandalous and immoral for the national legislators and other political office holders to be receiving the highest paid emoluments in the world for underperforming. Their salaries and remuneration should be drastically reduced in sync with prevailing realities and put the pay-cut into the National Employment Foundation Fund (NEFF) to provide and create employment for the mass of the unemployed youth in the country, after-all, employment is a right and not a privilege.

\section{Conclusion}

Unemployment, insecurity, harsh economic conditions among others indicate that young graduates in the polity are losing 
out while unconfirmed statistics indicate that three out of ten graduates in Nigeria are unemployed, some of them have become commercial motorcycle operators and patrol station attendants. To add to their frustration, some smart but dubious recruitment agencies have capitalized on their woes to exploit them under the guise of securing profitable jobs for them.

With the story of the Ph.D holders applying as drivers in Dangote companies still fresh in our memories and now the death of 20 urgent youths as a result of a stampede that occurred during the Nigeria immigration service, NIS employment sage, it shows that all the measures to check the scourge of unemployment have defied logic by successive governments. The percentage of labour force that is without job is alarming while the army of the unemployed and unemployed youths is frightening. Authorities have put the unemployed at 23 percent representing about 203 million Nigerians who are currently jobless.

The matter is compounded be daily as higher institutions churn out fresh gradates to add to the already saturated labour market. Expect for the bourgeoisie, there, there is no Nigerian household that does not have at loan one unemployed university, polytechnic or college of education graduate still searching for job.

The absence of basic infrastructure such as the incessant power outrage, the threatening security situation, corruption, unfriendly policies of the CBN, and business environment, and the increasing trend of disinterest by jobseekers in highly labour intensive works such as agriculture, factory work and creative business ideas in preference for white color job are some of the reasons that create unemployment. To reduce unemployment in the polity, the individuals concern, governments at all levels and the organized private sector must put in place creative measures to stem the tide.

Under this condition, it is doubtful how the youths of today can propel the needed wheel of development; if young people are provided with employment opportunities, they can become productive assets and take their part in main stream society offering the best of 'their skills and talent.

\section{References}

Agboola, T. (2014), "5000 Jobs coming as AMMASCO, NATA sign MoU", The Nation, Monday, March 31, Pp. 37-38.

Aiyedogbon, J.O. \& Ohwofasa, B. O. (2012), Poverty and Youth Unemployment in Nigeria, 1987-2011, International Journal of Business and Social Science, 3, (20) 269-279.

Akadoro, S. (2014), "Revamping Songhai Delta Amukpe: My Mandate-Okpidi, Daily Independent, Monday, March, 17. P. 9.

Central, Bank of Nigeria (CBN) (2012), Statistical Bulletin and Annual Report and Statement of Account (Various Issues) as Cite in Adeleke (2011), "Taxation, Revenue Allocation and Fiscal Federalism in Nigeria: Issues, Challenges and Policy Options," Economic Annals, 54, 189.

Eme,O.I(2013), "Insecurity and Nigeria's Business Climate," Journal of Policy and Development Studies, Vol. 7, No. 1, (May),Pp 81-98 Emeh, I.E., Nwanguma, E.O. \& Abaroh, J.J. (2012), "Engaging Youth Unemployment in Nigeria with Youth Development and Empowerment Programmes; the Lagos State in Focus," Interdisciplinary Journal of Contemporary Research in Business, 4,(5) 1125-1141.

http://www.InvestingAnswers.com/definition/unemployment-rate.html, (2014)

http://www.businessdictionary.com/definition/unemployment-rate.html, (2014)

International Labour Organization(2014),Global Employment Trends, Geneva: ILO

Iriekpen, D. (2014), "Boosting Job creation," ThisDay, April 1, Pp. 20-21

National Bureau of Statistics (2009), Labour Force Survey, Abuja: NBS.

National Bureau of Statistics (2010), Report of the National Bureau of Statistics Harmonized Nigeria living Standard Survey (HNLSS).

National Bureau of Statistics (2012), The Nigeria Poverty Profile, Abuja: NBS.

Nnadozie, C. (2014), "When Recruitment Exercise turned deadly in Niger," Daily Independent, Monday, March, 1, P 1.

Nweze, C. (2014), "On a higher Pedestal: Agric Financing on Front Burner", The Nation, Monday, March 31, Pp. 32-33.

Obike, G. (2014), "180 Vehicles for SURE-P Taxi Scheme", The Nation, Tuesday, February 25, P. 33.

Obinna, C. (2014), "Nigeria's Unemployment Rate May Rise by 2\%," Thisday, Tuesday, January 7, P. 32.

Odidi, G. (2014), "Challenges facing Nigerian Youths", Daily Sun, March 31, P. 21.

Okorocha, C. (2014), "Concern", The Nation, Tuesday, February 25, Pp. 4-5.

Omokhodion, L. (2014), "How Governments Can Attack the Unemployment Crisis," This Day, P. 31-32.

Osalor, P. (2014), "Breaking the Nigerian Poverty Cycle through Entrepreneurial Revolution Part I", Vanguard, Monday, March 31, P. 18.

Salif, A., Tony M., Tajudeen, S., Juliana, U. and Abiola O. (2014), Joblessness: Creating Vacancies for Explosion, News World, March 31, Pp. 14-23.

Sure-P (2012), Technical Vocational Education and Training (Tvet) Programme; Task list for Response to National Assembly, Nigeria: SURE-P Annual Reports, Abuja: SURE-P.

Sure-P (2013), Status Brief on Community Services, Women and Youth Employment, Nigeria: SURE-P Annual Reports, Abuja: SURE-P.

Sure-P (2013), Subsidy Reinvestment and Empowerment Programme, 2012 Annual Report, Nigeria: SURE-P Annual Reports Abuja: SURE-P.

U.S., the Bureau of Labor Statistics Reports (2014), Employment Situation Report, Washington D.C: Bureau of Labor Statistics 